\title{
Squamous Cell Carcinoma in the Third Eyelid of a Dog
}

\author{
Beatriz Crepaldi Aléssio, Juliana Paniago Lordello de Paula, Gustavo Gomes de Oliveira, \\ Silvana Marques Caramalac, Alda Izabel de Souza, Mariana Isa Poci Palumbo \& Veronica Jorge Babo-Terra
}

\begin{abstract}
Background: Squamous cell carcinoma is a malignant neoplasm that originates from the keratinized stratified squamous epithelium and predominantly affect light-skinned animals. In dogs, breeds such as American Staffordshire Terriers, white or speckled Bull Terriers, and Beagles have a higher predisposition. Squamous cell carcinoma presents in the skin, at slightly pigmented or hairy sites, especially in digits, but also may occur in the nasal planum, oral mucosa, and rarely, in the eye. Considering that few reports have been published on eye neoplasms, the aim of this paper is to describe a dog with a lesion in the third eyelid of his right eye which was diagnosticated with squamous cell carcinoma.

Case: A 10-year-old male American Staffordshire dog was admitted to the Veterinary Medical Teaching Hospital of the Veterinary Medicine and Zootechnics College, Universidade Federal de Mato Grosso do Sul (UFMS), Campo Grande, Brazil with injury to the right eye. During the physical examination, there was also a non-adhered lump near the foreskin, measuring $1.5 \mathrm{~cm}$ in diameter. In addition, there was another lump in the third eyelid of the right eye, approximately $3 \mathrm{~mm}$ in diameter. Cytology of the dermal nodule was performed by fine-needle aspiration cytology; however, the sample was insufficient for cytological evaluation. Therefore, the animal was placed under general anesthesia for skin lump excision and for fine-needle aspiration cytology of the third eyelid nodule. The histopathological exam revealed high cellularity of epithelial cells, intense anisocytosis and pleomorphism, cytoplasmic basophilia and vacuolation, multiple evident nucleoli, and anisocariosis and coarse chromatin. These finds were compatible with squamous cell carcinoma, which was the same result suggested by fine-needle aspiration cytology of the third eyelid sample. Based on these results, the dog underwent a surgical procedure for enucleation and subsequent histopathological evaluation of the nodule in the third eyelid, which confirmed the squamous cell carcinoma diagnosis.

Discussion: Squamous cell carcinoma is an extremely aggressive tumor with low metastatic potential, characterized by invasion of the dermis by proliferation of malignant epithelial cells from the prickly layer. It is most common in elderly animals, and American Staffordshires are among the breeds that are predisposed to develop this tumor. The clinical presentation is highly variable, depending on the tissue involved. In this case, the dermal nodule was an elevated area on the skin and the third eyelid nodule resembled an ulcerative mass. Cytological examination from the lesion located on the third eyelid, showed malignancies cytoplasmic changes frequently found in carcinomas such as anisocytosis, cytoplasmic basophilia, and cell pleomorphism. In addition, nuclear changes had also occurred, such as crass chromatin, multiple evident nucleoli, and multinucleated cells. A presumptive diagnosis was made based on cytology and was confirmed after biopsy and histopathological examination. Because it is uncommon in dogs, squamous cell carcinoma of the third eyelid may be misdiagnosed, delaying correct treatment, and accelerating the development of the tumor. Currently, various therapeutic approaches are available, such as surgical excision, electrosurgery, cryosurgery, radiation, and hyperthermia. The choice of treatment depends on the location and stage of the lesions. Surgical treatment should be aimed at removing sufficient tissue to leave surgical margins free of neoplastic cells.
\end{abstract}

Keywords: neoplasm, ocular squamous cell carcinoma, oncology. 


\section{INTRODUCTION}

Approximately $25 \%$ to $35 \%$ of all neoplasms in dogs are malignant. Primary ocular cancers are relatively rare and, consequently, little studied, whereas secondary forms are more common and are always related to metastasis of non-eye neoplasms [8].

Squamous cell carcinoma (SCC) or epidermoid carcinoma, is a malignant neoplasm that originates from the keratinized stratified squamous epithelium [1] and may originate in the eye conjunctival limbus bulb, the nictitating membrane, bulbar conjunctiva, or eyelid epidermis, and is most common in cats, cattle, horses, and humans, but is rarely described in dogs $[5,6,9]$.

SCC is one of the most common cutaneous tumors, predominantly affecting light-skinned animals and its occurrence increases from middle age [4]. Breeds such as American Staffordshire Terriers, white or speckled Bull Terriers, and Beagles have a higher predisposition [9,11].

In dogs, SCC presents in the skin, at slightly pigmented or hairy sites [11]; the digits, representing $25 \%$ to $52 \%$ of all neoplasms that occur at this location [7]; the nasal planum, which may be associated with cutaneous erythematosus lupus, pemphigus, and vitiligo; the oral mucosa, constituting the most common oral neoplasia in dogs [11]; and rarely, the eye [7]. Considering that few reports have been published on eye neoplasms in dogs, the aim of this paper is to report a rare case of SCC in the third eyelid of a dog.

\section{CASE}

A 10-year-old male American Staffordshire dog was admitted to the Veterinary Medical Teaching Hospital of the Veterinary Medicine and Zootechnics College, Universidade Federal de Mato Grosso do Sul (UFMS), Campo Grande, Brazil with a history of injury to the right eye, incurred approximately 45 days prior to admission. During the physical examination, we noticed the presence of ticks and a non-adhered lump with a soft consistency near the foreskin, measuring 1.5 $\mathrm{cm}$ in diameter. In addition, there was another lump in the third eyelid of the right eye, approximately $3 \mathrm{~mm}$ in diameter (Figure 1).

Cytology of the dermal nodule was performed by fine-needle aspiration (FNA); however, the sample was insufficient for cytological evaluation. At this point, it was not possible to collect a sample from the third eyelid lump. A complete blood count showed normocytic normochromic anemia (globular volume: $32.7 \%$, ref. $37 \%$ -
$55 \%$ ), leukopenia (5.400 cells $/ \mathrm{mm}^{3}$, ref. $6.000-17.000$ cells $\left./ \mathrm{mm}^{3}\right)$, activated monocytes, and thrombocytopenia $\left(30,000\right.$ cells $/ \mathrm{mm}^{3}$, ref. $200.000-500.000$ cells $\left./ \mathrm{mm}^{3}\right)$. The dog was treated for ehrlichiosis, after which the complete blood count was repeated and all values were within normal ranges. The animal was placed under general anesthesia for skin lump excision and for FNA cytology of the third eyelid nodule.

The histopathological result of the dermal nodule was SCC, which was the same result suggested by FNA of the third eyelid sample, revealed high cellularity of epithelial cells, intense anisocytosis and pleomorphism, cytoplasmic basophilia and vacuolation, multiple evident nucleoli, and anisocariosis and coarse chromatin. Based on these results, the dog underwent a surgical procedure for enucleation and subsequent histopathological analysis with Hematoxylin ${ }^{1}$ and $\operatorname{Eosin}^{2}$ dyes of the nodule in the third eyelid.

The result of the histopathological examination of the third eyelid lump confirmed SCC (Figure 2 ), with epithelial architecture disorganization on the outside surface of the apical portion. The epithelium issued fronds and nests into the submucosa and multifocal loss of contiguity with the surface had occurred (Figure 2A). Tumor stroma was scarce.

Neoplastic epithelial cells were typical, predominantly exhibiting pleomorphism and anisocytosis and multifocal anisocariosis. In general, the cytoplasm was abundant and slightly delimited. The core was oval and centrally located, with finely vacuolized chromatin, and the nuclei were generally inapparent. Mitoses were scarce. Multifocally, keratinocytes were individualized with evident eosinophilic cytoplasm and pyknotic nuclei, separated from neighboring cells by a crack (indicating apoptosis).

Rarely, in the center of the nests, keratinocytes were elongated and arranged in concentric lamellae. Multifocally, collagen of the submucosa was lightly basophilic. A cloak of lymphocytes and plasma cells covered the tumor (Figure 2B). Next to the epithelium, among the inflammatory infiltrate, there were macrophages containing granular and golden pigment in the cytoplasm (hemosiderin) and few free red cells. The end of the cartilage was minimally disorganized and invaded by the tumor.

\section{DISCUSSION}


According to the clinical and histopathological findings, the lesions observed are compatible with a diagnosis of SCC, a highly aggressive tumor with low metastatic potential, characterized by invasion of the dermis by proliferation of malignant epithelial cells from the prickly layer, as previously described [4]. SCC is most common in elderly animals [4], and American Staffordshires are among the breeds that are predisposed to develop SCC [9]. Cutaneous SCC most commonly affects the ventral region of the body [11]. In a retrospective study of third eyelid neoplasms in dogs and cats, 145 dogs were evaluated and only one $(0.8 \%)$ was diagnosed with SCC of the third eyelid,

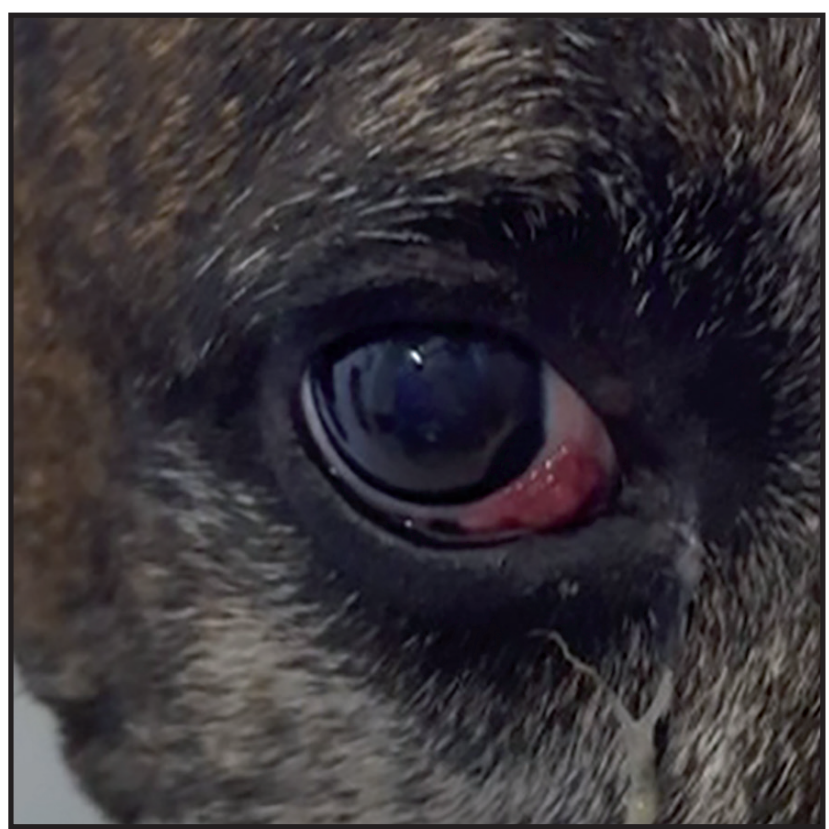

Figure 1. Nodule with a diameter of approximately $3 \mathrm{~mm}$ in the third eyelid of the right eye. [Source: Department of Small Animals Medical Practice - UFMS]. highlighting the rarity of this presentation in dogs [3]. A literature review conducted in the present study revealed only two reports of SCC in the third eyelid in Brazil, one in a dog and the other in a cat $[2,8]$, confirming that is unusual to find SCC in the third eyelid of companion animals.

The clinical presentation of SCC is highly variable, depending on the tissue involved. In this case, the dermal nodule was an elevated area on the skin and the third eyelid nodule resembled an ulcerative mass, corroborating previous reports [6].

Cytological examination showed cytoplasmic changes in the epithelial cells of the lesion located on the third eyelid, such as anisocytosis, cytoplasmic basophilia, and cell pleomorphism. In addition, nuclear changes had also occurred, such as crass chromatin, multiple evident nucleoli, and multinucleated cells. All these changes are considered as malignancies frequently found in carcinomas [12].

A presumptive diagnosis was made based on cytology and was confirmed after biopsy and histopathological examination [11]. Since it is uncommon in dogs, SCC of the third eyelid may be misdiagnosed, delaying correct treatment and accelerating the development of the tumor [6]. In this case, we promptly recommended FNA for cytological examination of the ocular mass to confirm our suspicions as soon as possible, and histopathology was later performed to confirm the diagnosis.

Currently, various therapeutic approaches are available, such as surgical excision, electrosurgery, cryosurgery, radiation, and hyperthermia. The choice

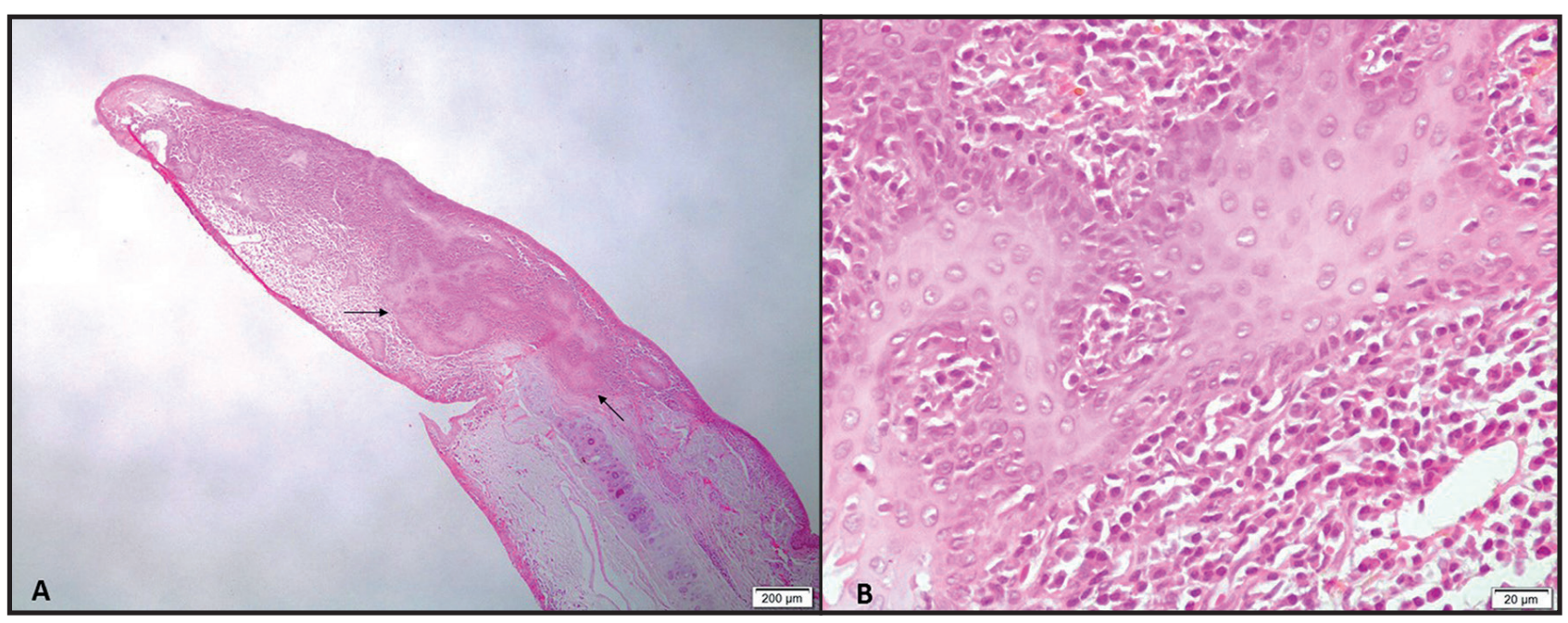

Figure 2. Squamous cell carcinoma in the third eyelid of a dog. A- Invasion of malignant epithelial cells with loss of contiguity with the surface [HE; 10x]. B- Nests of neoplastic epithelial cells surrounded by inflammatory infiltrate composed of lymphocytes and plasma cells [HE; 40x]. [Source: Pathology Laboratory - UFMS]. 
of treatment depends on the location and stage of the lesions. Surgical treatment should be aimed at removing sufficient tissue to leave surgical margins free of neoplastic cells [11]. In this animal, the selected treatment option was dermal nodule excision and enucleation of the affected eye because despite its low metastatic potential, the tumor was malignant and locally invasive [10].
MANUFACTURERS

${ }^{1}$ WCOR Corantes. São Paulo, SP, Brazil.

${ }^{2}$ Vetec Química Fina Ltda. Rio de Janeiro, RJ, Brazil.

Acknowledgements. This study was financed in part by the Coordenação de Aperfeiçoamento de Pessoal de Nível Superior - Brasil (CAPES) - Finance Code 001.

Declaration of interest. The authors report no conflicts of interest. The authors alone are responsible for the content and writing of the paper.

\section{REFERENCES}

1 Belluco S., Brisebard E., Watrelot D., Pillet E., Marchal T. \& Ponce F. 2013. Digital squamous cell carcinoma in dogs: epidemiological, histological, and imunohistochemical study. Veterinary Pathology. 50(6): 1078-1082. DOI: 10.1177/0300985813490757

2 Conceição M.E.B.A.M., Martins D.M., Bertolo P.H.L., Bezerra D.K.O., Silva C.D.C.F, Aguirra L.R.V.M., Vasconcelos R.O. \& Pereira W.L.A.2016. Carcinoma de células escamosas em terceira pálpebra de felino. Acta Scientiae Veterinariae. 44(1): 170. 5p.

3 Dees D.D., Schobert C.S., Dublielzig R.R. \& Stein T.J. 2016. Third eyelid gland neoplasms of dogs and cats: a retrospective histopathologic study of 145 cases. Veterinary Ophthalmology. 19(2): 138-143. DOI: 10.1111/vop.12273

4 Goldschmidt M.H. \& Goldschmidt K.H. 2017. Epithelial and Melanocytic Tumors of the Skin. In: Meuten D.J. (Ed). Tumors in Domestic Animals. 5th edn. Ames: Wiley Blackwell, pp.97-99.

5 Karasawa K., Matsuda H. \& Tanaka A. 2008. Superficial keratectomy and topical mitomycin C as therapy for a corneal squamous cell carcinoma in a dog. Journal of Small Animal Practice. 49(4): 208-210. DOI: 10.1111/j.17485827.2007.00402.x

6 Montiani-Ferreira F., Kiupel M., Muzolon P. \& Trupprl J. 2008. Corneal squamous cell carcinoma in a dog: a case report. Veterinary Ophthalmology. 11(4): 269-272. DOI: 10.1111/j.1463-5224.2008.00622.x

7 Northrup N. \& Gieger T. 2010. Tumors of the skin, subcutis and other soft tissues. In: Henry C.J. \& Higginbotham M.L (Eds). Cancer Management in Small Animal Practice. St. Louis: Elsevier, pp.299-328.

8 Redaelli R., Albuquerque L., Faganello C.S., Rodarte A.C., Marques J.M.V., Oliveira L.O., Leal J.S., Driemeir D. \& Pigatto J.A.T. 2007. Carcinoma das células escamosas na terceira pálpebra em um cão. Acta Scientiae Veterinariae. 35 (2): 644-645.

9 Rodaski S. \& Werner J. 2009. Neoplasias de pele. In: Daleck C.R., Nardi A.B. \& Rosaski S. (Eds). Oncologia em Cães e Gatos. São Paulo: Editora Roca, pp.254-259.

10 Rogers K.S. 1994. Feline cutaneous squamous cell carcinoma. Feline Practice. 22(5): 7-9.

11 Scott D.W., Miller W.H. \& Griffin C.E. 2001. Muller \& Kirk's Small Animal Dermatology. 6th edn. Philadelphia: W.B. Saunders, pp.1236-1415.

12 Young K.M. \& Prasse K.W. 2009. Os olhos e as estruturas associadas. In: Cowell R.L., Tyler R.D., Meinkoth J.H. \& Denicola D.B. (Eds). Diagnóstico Citológico e Hematológico de Cães e Gatos. 3.ed. São Paulo: Med Vet, pp.149-171. 